\title{
Assessing geopolitics as Nepal's national security challenge
}

\section{Bikash Dhakal}

\begin{abstract}
The increased geo-strategic interests and concerns of great powers have posed serious challenges to national security of Nepal. This article objectively analyzes the impacts of geopolitics on Nepal's national security. It intends to examine the National security within the framework of geopolitical rivalry. Geopolitics is rather a crucial external factor than the other internal factors of insecurity. Thus, this article attempts to justify how regional and global geopolitical developments challenge Nepal's national security. This article explains geopolitical factors that can pose threat and challenge to national security.
\end{abstract}

Keywords: geopolitics, national security challenge, geo-strategy, geo-economics

\section{Introduction}

Security is one of the most important issues in both national and international politics, so the governments of powerful states around the world spend a tremendous amount of money on their national security. Yet, small states like Nepal and South Korea cannot just make attempts to ensure their national security. On the one hand, Nepal does not have capacity to deal with nuclear insider militarily and financially. On the other hand, its geographical setting is another major factor in its "insecurity" in the global context.

Geographically, fact, Nepal is squeezed between world's two rising powers: China and
India. Moreover, China and India themselves are rivals because of differences on several fronts. With the economic and political rise of China, Nepal has ever-increasing regional and international interests. Due to its unique geo-strategic location, the strategic intentions of China, India and the US are deeply rooted in Nepal. Unfortunately, Nepal has become a gigantic area of triangular struggle for power.

National Security Policy of Nepal 2016 indicates to strategic interests of regional and global powers as major security challenge to the country. Big powers geopolitical moves have defiantly created challenges on national security. Among others, geopolitics is one of the major factors to challenge and threat to Nepal's national security.

The national security of any state can be presented from geopolitical strategic perspective. In addition to its power relations and global behaviors, geopolitical framework is an integrated study of geography of a state. This article discusses geopolitical aspects of Nepal's national security in the following sections.

\section{New creed on the national security}

National security's primary purpose is to protect the state and its people from all sorts of threats, both domestic and international. Equally, it is an ability of state to protect the internal values from the external threats or aggression. But, the concept of national security in the modern era does not only 
denote conventional military-political approaches only. Under the domain of nonconventional security approaches, many other entities tend to contribute to broaden the concepts of security.

The conventional security approaches applied exclusively to the military threat. Nevertheless the non-conventional concepts are now at the fore-front of the economic, environmental, socio-cultural, technological and other challenges to national security. On an issue of national security, the new power competition does not necessarily focus on the direct territorial control, but on informal influence. And the tool of influence on the international relations from the part of the small states like Nepal and Bangladesh could be the "soft power" rather than hard power or sharp power. In that case, a persuasive approach to international relations, typically involving the application of economic and cultural influence, can be the right strategy to influence the global power. Scholars of international relations have long recognized that differential rates of economic growth lead to structural changes in the balance of power (Gilpin, 1981 \& Kennedy, 1989). In the context of changing strategic facts on this ground, there are various new creeds on national security challenges.

\section{Geopolitical organism of Nepal}

Geopolitically, states political power and security policy are determined by geographic characteristics. Nepal's situations were fragile through the prism of geopolitics even from the days of formation of the modern nation -state around the mid-eighteenth century under the leadership of the Gorkha King Prithvi Narayan Shah. Founder King PN Shah, in his maxim, proclaimed that "Nepal is a yam between two boulders". His perception of the country explicates Nepal's defensive strategy in the situation that Nepal was facing external threats from the East India Company along the powerful states and principalities across India at that time. King PN Shah's proclamation toward the last quarter of the eighteenth century has become a vital guideline to Nepal's foreign policy.

Despite Nepal's defensive non -aligned strategies of international relations, the offensive policy of great powers towards Nepal has great geopolitical implications in Nepal. Nepal's geographic position has undoubtedly affected its foreign policies and external presence in the regional and global arena. In recent years, Nepal's position has got to be deliberately more significant than in the past primarily because of the rise of the two Asian giants, including India and China. Because of its geography, Nepal is suffering within the strategic rivalry of great powers. In such a point in case, geopolitics has consistently become a crucial determinant to Nepal's foreign policy and international affairs.

\section{National security on geopolitical framework}

The external threat and the problem of survival in the sense of national security are closely related to the geopolitical objective and subjective effects. In this context, geopolitics is such a structural framework that can provide ideas to identify external threats to national security.

Geopolitical study is simply an emphasis on the relationship between geographical facts on the one hand and international politics on the other (Colin, 2013, p. 1). Geopolitics can, therefore, be defined as "the relation of international political power to the 
geographical setting" (Cohen, 1973, p. 24). Classical geopolitical analysis affirms that an "international system is a competitive arena in which great powers play a disproportionate role, struggling for security, resources, position and influence" (Colin, 2013, p. 3). Whereas critical geopolitics emphasizes the ways images of the world are created, transmitted and underpin geographies of power and conflict (O'Tuathail, 1996, p. 60).

Traditionally, geopolitical perspectives are only characterized by the rivalry of powers and global demarcation of powers. However, geopolitics in recent decades incorporates analysis of non-political development and cooperation with strong emphasis on individual and community participation in the changing geopolitical spheres.

Critical geopolitical discourse not only analyzes traditional state and power centered geopolitics but also applies social-scientific critical thinking to inquire the power dynamics. The geopolitical framework should, therefore, be analyzed, and external threats to non-conventional challenges to national security should be identified. The following discussion section responds to a genuine research question why geopolitics is vital to Nepal's security.

\section{Discussion}

\section{The global strategic shift}

Today's international politics on both global and regional levels are very different from those of earlier centuries. International power is shifting from the Pacific Ocean towards Asia-Pacific gradually. Because of its expanding economic power, Asia is expected to play a prominent role in the twenty-first century.
According to Joseph Nye (2015) "China's size and its high rate of economic growth will bring it closer to the United States in terms of the basic resources for influence over the next few decades" (Nye, 2015). Indeed, China is upgrading its military, increasing its defense budget and improving its alliances. Although the US's focus on China has reached a high point in recent years, this change reflects a longer-term recognition of the need to shift America's focus to Asia in general and China in particular (Anthea, Henrique \& Victor, 2018). The security policy and economic interests of the US is shifting towards Asia. The growing military and political stakes of the US and its mere presence in the area is a reflection of offensive realism's growing functioning (Khan \& Amin, 2015, p. 15).

As China's economic and military power is on rise, it is in the struggle for the new world order. Accordingly, Belt and Road Initiatives (BRI) initiated by Chinese President Xi Jinping is a grand geopolitical strategy of China. BRI is a large connectivity project designed to merge separate plans with a grand objective of connecting three continents Asia, Europe and Africa through land and maritime routes. It is an ambitious project with geopolitical and geo-economic ambitions.

Under these circumstances, rise of China is a great threat to the established super power like the US and its liberal world order. Consequently, the US is revolving around Chinese territories to encircle it. Therefore, the US President Donald J. Trump's IndoPacific Strategy (IPS) forwarded new major strategic plan, the composite iteration of all earlier government's strategy is deeply rooted in its geo-strategic interests. IPS is the geo-strategic weapon to threat and counterbalance the Chinese influence in the Asia Pacific region. 
Hence, the US foreign policy towards Nepal reflects the border regional context. Since Nepal is strategically important for the US. Accordingly, China looks for the more dynamic back of Nepal for its One China approach. What China believes is that Nepal is the guarantor of the Tibetan region's security and stability and its strategically important Belt and Road Initiatives.

Against the 'One China Policy', the US and its allies intend to contain China by pushing it into inconvenience by supporting free Tibet movement and human right issues. To this end, the US wishes to have a strategic pact with Nepal, a strategically important nation that sincerely endorses China's official recognition of its one sovereign state with unalienable parts, including Tibet, Taiwan, Macau and Hong Kong.

Apart from security and economic interests, China has interest in containing the US influence in Nepal. Consequently, the prospect of potential confrontation rather than possibility of cooperation in the global geopolitical climate pose a great challenge to Nepal's national security.

\section{Convergence of geo-economics with geopolitics}

In the last couple of years, economic power developed as one of the biggest nontraditional challenges to national security. Economic power has been one among other asymmetric strategic tools that can easily trickle down, even the military power also. Geo-economics is mainly 'the geo-strategic use of economic power' (Wigell, 2016, p. 137).

Geo-economics proceeds from the assumption that power and security are not simply coupled to the physical control of territory, as in classical geopolitical analysis, but also to commanding and manipulating the economic ties that bind states together. Geo-economics provides a way for states to conduct power politics that does not refer to military means (Scholvin \& Wigell, 2018, p. 74). As a foreign policy strategy, it refers to the application of economic means of power by states so as to realize strategic objectives.

Nepal is the one among other Asian strategic core where Geo-economic strategies of big powers are not separated from their security policies. As weak infrastructures, less use of resources and regional imbalance in terms of development are the major sources of conflict that may pose serious security threat to the small countries (Khanal, 2010, p. 101). Geo-economics is such powerful instrument through which big powers can easily influence small states, such as Nepal and Bhutan to change their patterns of behaviors and international relations. Geoeconomics can bring about disastrous shifts in the regional geopolitics. The inherent asymmetric contradictions and dependencies in the international system make economic power an effective means of achieving strategic goals in Nepal.

China is using finance, investment and trade to build alliances and influence countries across Africa, Asia and Latin America (Yu, 2015, p. 1048). As in other areas of the region , China has increased the volume of pledging grant assistance to Nepal government and expenditure in strategic sectors in Nepal.

In this state of affairs, not only China but also India is increasing aid and investment in various strategic sectors in Nepal. Nepal has been benefited from the economic assistance of both India and China considering the economic raise of both countries such 
assistance could provide substantial benefits in the future (Thapa, 2012, p. 12). To take geo-economic leverage and to compete with China, India is also in desire to expand further assistance and concessions. However, India's ledge is not being fulfilled because India lacks strong economic backup as China does.

By forwarding geo-economics as their foreign policy instruments, the US and China are increasing assistance to Nepal in the strategic sectors. But in promoting geo-economic movements on its spheres of influence areas, India is far behind because of its own limitations.

Big external powers 'soft power' foreign policy instruments-economic policy that are focused on achieving their strategic interests has significant geo-economic implications in Nepal. It refers to the use of economic power means to achieve strategic goals. So the new trend of convergence of geo-economics with geopolitics poses threats to national security of Nepal.

\section{Immediate neighbors rivalry}

The interests of China and India in Nepal are mainly geo-strategic. Nepal is in the strategic needs for both of its immediate neighbors; China and India. Nepal's geographical uniqueness makes it vital for its neighbors' security.

The recent rivalry between China and India in Nepal is aimed at minimizing China's growing influence and keeping Nepal friendly to India in all areas of interest and China's geo-economic strategy of enhancing strategic alliance and partnership by increasing economic clout. Professor Hunag argues that "with Belt and Road Initiative going on, South Asia is an area that China must engage in, so if China wants to open up further to south Asia , Nepal is an important channel" (Hunag, 2018).

China looks towards Nepal first with its security concerns. Whereas India is also an ambitious and strong regional power, its major concern in Nepal lies on its domestic security sensitivity. As Nepal and India share open and absorptive borders, the former's political stability and security are the latter's major concerns. Similarly, China primarily intends to reduce Nepal's reliance on India and to maintain Nepal as a strong and independent neutral state. Nepal has a vital strategic importance to India, so it obviously feels worried about any foreign presence and interests in Nepal. Together with its political and security concerns, India has prominent financial maneuvers in Nepal.

Despite their strong bonds over multiple aspects, India and Nepal share concerns over the 1950 Treaty that places Nepal on a common defense framework with India. India barely responds to Nepal's voice on the revision of the treaty. As a strong regional power with an ever growing economy along with the military capability, India invariably sustains its hegemonic engagements in South Asian countries, including Nepal, Bhutan and Bangladesh, which underlines New Delhi's inability to be a proactive shaper of regional security is the fact that it lacks a strategic vision of its regional role (Thapa, 2012, p. 11).

The Indian and Chinese rivalry persists over decades because of their geographic proximity as well as strong military capabilities. In this backdrop, Nepal should be able to maintain its neutrality in respect to its neighbors' concerns in line with Manish Thapa's argument: 
It is necessary for Nepal to understand the sensitivity of India and China in terms of their security related issues and adopt policies wisely, following a middle path, that respects the interests of both neighbors without endangering its own sovereign and independent position. (Thapa, 2012, p. 11)

Realizing these geopolitical strategies, Nepal can justify its strength in respective its neighbors' security concerns. As a small state, Nepal respects their sovereignty while consistently cooperating with them to settle issues on multiple fronts.

\section{Conclusion}

Geopolitics is not much of Nepal's interest, but geopolitics definitely affects Nepal's international relations and national security. Nepal's national security is in vulnerable situation in terms of geopolitics, where geopolitical rivalry between major powers obviously persist this small's state's diplomacy and relationships with other countries across the world. Competitive strategies in geopolitics do not rule out the possibility of cooperation in geopolitical grappling rather they lead to a sharp increase in geopolitical challenges to the national security of small state Nepal.

Under these circumstances, geopolitics in its growing threats stands major national security challenge. In the meantime, internal balance along with external cooperation is Nepal's major challenge. In response to the challenges created by new geopolitical developments, Nepal has to identify pragmatic strategies to stabilize big powers.

Nepal's comprehensive national security strategy basically depends upon capacity of political leadership. Indeed, political leaders and diplomats need to have proactive foreign policy and pragmatic diplomacy in order to cope with geopolitical intricacy for safeguarding national interests.

National security is a complex and multifaceted topic. National security concerns should be reviewed from broader perspectives. In Nepal's case, new geopolitical situations are more complex today than in the past.

Today's world is more interdependent and intertwined in history than ever before. So, geopolitics has become one of the prominent phenomena that poses a great challenge to Nepal's national security. Geopolitics can immensely affect Nepal's national security. To defend its national interests and safeguard the future, it is a high time to formulate new perspectives on pragmatic diplomatic strategy. Nepal must, therefore, reframe its mindset of small country syndrome and bring the renaissance of proactive diplomacy.

\section{References}

Anthea, R., Henrique, C. M. \& Victor, F. (2018). Geo-economics: The variable relationship between economics and security, Retrieved from: https://www.lawfareblog. com/geoeconomics-variable-relationshipbetween-economics-and-security

Cohen, S. (1973). Geography and politics in a divided world. New York: Oxford University Press, p. 34.

Colin, D. (2013). Geopolitics reborn, foreign policy Research Institute. Retrieved from :https://www.fpri. org/docs/Dueck-Geopolitics_Reborn.pdf

Gilpin, R. (1981). War and change in world politics. New York, NY: Cambridge University Press.

Hunag, Z. (2018). Professor, Nepal Study Center Sichauwan University, China Personal Communication, December 18, 2018. 
Nye, J. (2015). Interview: Joseph Nye. The Diplomat, By Emanuel Pastreich. Retrieved from: https://thediplomat. com/2015/10/interview-joseph-nye-2/

Kennedy, P. (1987). The Rise and fall of the Great Powers. New York: NY: Random House.

Khan, Z \& Amin, F. (2015). 'Pivot' \& 'Rebalancing': Implications for AsiaPacific region policy perspectives. Pluto Journals Stable 12 (2), 3-28. Retrieved from: http://www.jstor.org/stable/10.13169/polipers on 12 February 0003

Khanal, R. (2010). Security of small states. Journal of Political Science, 12 (2). Central Department of Political Science Tribhuvan University, Kritipur, Kathmandu, Nepal.

Ó Tuathail, G. (1996). Critical Geopolitics: The politics of writing global space. Minneapolis: University of Minnesota Press. P. 60.
Scholvin, S. \& Mikael, W. (2018) Power politics by economic means: Geo-economics as an analytical approach and foreign policy practice, Comparative Strategy, 37:1, 73-84, DOI:10.1080/01495933.2018.1419729

Thapa, M. (2012). The Great Himalayan game: India and China rivalry in Nepal. Contemporary South Asia, 1-14.

Wigell, M. (2016). Conceptualizing regional powers geo-economic strategies: Neo imperialism, neo-mercantilism, hegemony, and liberal institutionalism, Asia Europe Journal 14.2: 135-51.

Yu, L. (2015). China's strategic partnership with Latin America: A fulcrum in China's rise. International Affairs 91.5: 1047-608. 